\title{
AMERIKOS LIETUVIŲ TARYBOS XX A. 5 DEŠIMTM. VIZIJA - IŠLAISVINTA \\ LIETUVA: TARP SEIMINĖS IR PREZIDENTINĖS RESPUBLIKOS
}

\author{
DR. JUOZAS BANIONIS
}

Lietuvos gyventoju genocido ir rezistencijos tyrimo centras

Genocide and Resistance Research Centre of Lithuania

Didžioji g. 17/1, LT-01128 Vilnius

Vilniaus pedagoginis universitetas

Vilnius Pedagogical University

Studentu g. 39, LT-08106 Vilnius

El.paštas j.banionis@vpu.lt

\section{Santrauka}

Straipsnyje aptariamos Lietuvos laisvinimo veiklos užuomazgos JAV. Čia jau XX a. penktajame dešimtmetyje aktyviai reiškèsi senoji lietuviu išeivija. Išeiviai, veikdami per politines grupes ar sroves, dar 1940-uju rugpjüti isteigé Lietuvai gelbèti taryba (toliau-LGT), kuri 1941 m. gegužès mèn. pakeite pavadinima i Amerikos lietuviu taryba (toliau - ALT). Ǐs pradžiu ši organizacija vienijo keturias pagrindines išeivijos politines sroves: katalikus, socialistus, sandariečius ir tautininkus, tačiau netrukus šiq vienybę sutrikdè skirtingas požiūris i 1926-uju ivykius Lietuvoje ir būsimos Lietuvos santvarkq. Todèl tautininkai, palankiai žiürèdami i Prezidentq Antanq Smetonq, atsiskyre nuo organizacijos ir $1941 \mathrm{~m}$. birželi ikūrè Lietuvai vaduoti sajungq (toliau-LVS). Po tragiškos Prezidento žūties (1944 m. sausio 9 d.) vasario mèn. pastaroji organizacija persitvarke i Amerikos lietuviu misija (toliau-ALM).

Toks Lietuvos laisvinimo veikla užsiimančiu dvieju organizaciju egzistavimas JAV buvo kliütis formuoti bendra politikq. Vis dèlto 1947-aisiais autoriteta Vakaruose išsikovojusio Vyriausiojo Lietuvos išlaisvinimo komiteto (toliau - VLIK) pastangomis pavyko šias organizacijas suvesti i derybas ir 1948 m. sausį ALT vè sujungè keturias patriotines lietuviu politines sroves. 
Reikšminiai žodžiai: Amerikos lietuvių taryba; Amerikos lietuvių misija; demokratiné Lietuva; 1922 m. Konstitucija; 1938 m. Konstitucija.

1940-ujų vasaros įvykiai Baltijos valstybėse ir juos lydejjusi sovietų okupacija pakèlè lietuviųišeivius aktyviai politinei veiklai. Vos prasidèjus Lietuvos sovietinei okupacijai, 1940 m. birželio 15 d. Leonardas Šimutis, Amerikos lietuvių Rymo katalikų susivienijimo (toliau - ALRKS) pirmininkas ir Amerikos lietuvių Rymo katalikų federacijos (toliau-ALRKF) sekretorius, Čikagoje sušaukè lietuvių veikèjų pasitarimą. Buvo sudaryta komisija (i ją ièjo dr. Steponas Biežis, dr. Antanas Rakauskas, juristas Kazys Česnulis ir L. Šimutis), kuri turëjo parengti griežtą protesto prieš sovietų agresiją Baltijos kraštuose telegramą ir įteikti ją JAV valstybės sekretoriui Kordelui Halui (Cordell Hull) $)^{1}$. Sudaryta komisija kūre ir tolimesnès veiklos, stojant į Lietuvos nepriklausomybės sargyba, gaires. Pirmiausia ALRKF priimtuose dokumentuose atsirado mintis steigti bendrą Lietuvos reikalu gynimo tarybą. Dar 1940 m. liepos mèn. pradžioje ši katalikiškos krypties organizacija pasiūlè visoms partinėms srovèms ir ideologinėms grupèms, kovojančioms dèl Lietuvos nepriklausomybès, rasti „bendrą kelią dirbti bendrajam tikslui“. Taip pat dokumentuose pabrěžta, kad „Maskvai pasidavę lietuviai komunistai ir visi jų simpatikai visiškai atskiriami iš lietuvių visuomenès ${ }^{\text {“2 }}$. Vadinasi, buvo nubrež̌ta aiški takoskyra, kuri atribojo pačius kairiausius lietuvius, ir jie dabar buvo laikomi ne tik ideologiniais priešais, bet ir „Lietuvos ir lietuvių tautos priešais“. Tokią griežtą poziciją lèmė Amerikos komunistų partijos Lietuvių skyriaus viešos pagyros sovietinei okupacijai Lietuvoje.

Netrukus - 1940 m. liepos 23 d. buvo sulaukta JAV valstybės sekretoriaus Samnerio Velso (Sumner Welles) viltingo pareiškimo, kuriame išdèstyta oficiali JAV pozicija dèl ivykių Baltijos valstybèse. Pareiškimas pradedamas tokiais žodžiais: „Paskutinèmis keliomis dienomis blogi ịvykiai, kurių ittakoje trijų mažų Baltijos respublikų-Estijos, Latvijos ir Lietuvos, politinè nepriklausomybè ir teritorinè nekeičiamybė sąmoningai siekiama sunaikinti vieno jų daug galingesnio kaimyno, eina prie savo galo"3. Toliau išdèstomi bendri politikos principai: ,Jungtinių Valstijų žmonès priešinasi grobuoniškiems veiksmams, nežiūrint ar jie yra padaromi nenaudojant jègą arba grasinimu jèga. Jie taip pat priešinasi bet kokiai kitai formai, nors ir galingos valstybès ${ }^{44}$. Taip pat patikinama, kad ,Jungtinès Valstijos ir toliau laikysis šių principu, nes Amerikos žmonès isitikinę, kad išminties, teisingumo ir teisès - kitais žodžiais, moderniosios civilizacijos

1 Šimutis, L. Amerikos lietuviu taryba: 30 metu Lietuvos laisvès kovoje 1940-1970. Chicago, 1971, p. 16.

2 Mūsų Tautinès pareigos. Draugas. 1940, liepos 5; Skirius, J., Račkauskas, J. Amerikos lietuviu tarybos kūrimosi 1939-1941 metais atspindžiai dokumentuose ir spaudoje. Chicago, 1998, p. 85.

3 Dabartinè Lietuvos tarptautinè padètis. Lietuviu dienos. 1950, Nr. 5, p. 5.

4 Ten pat. 
pagrindų - išlaikymas yra neįmanomas, kol doktrina, kurioj slypi šie principai netvarko santykių tarp tautų “5.

1940 m. rugpjūčio 14 d. socialistų laikraštis „Naujienos“ paskelbè straipsni „Su kuriais mums pridera dètis kovoje už Lietuvos Nepriklausomybę“. Tai buvo reikšmingas raginimas baigti partijų rietenas ir vienytis bendrai laisvinimo veiklai. Straipsnyje teigiama: „Atsižvelgiant $\mathfrak{i}$ Lietuvos prismaugimą ir lietuvių kančią, tenka tuščias kalbas ir visokius burbulus prieš Smetonas, Smetonienes, ir bolševikų,„Laisves““ palikti pasamdytiems Rusijos agentams, Nepriklausomos Lietuvos ir Lietuvos tautos priešams, o sąmoningiems lietuviams, kuriems žinoma, kas yra Valstybės ir Tautos laisvè, prisieina neatidèliojant stoti i Lietuvių Frontą ir kovoti už visiems bendrą ir brangią idèją ir idealą - Laisvą ir Nepriklausomą Lietuvąa".

Atrodè, kad ši raginimą JAV lietuviai išgirdo. Ir jie, pakilę i Lietuvos nepriklausomybės sargyba, sulaukė palankaus oficialios valdžios pareiškimo. Tai buvo patvirtinta 1940 m. rugpjūčio 9-10 dienomis vykusiame ALRKF suvažiavime, kai paskelbta apie steigiamą organizaciją - centrą - Lietuvai gelbèti tarybą (toliau - LGT). Šis Pitsburge sušauktas suvažiavimas priimtoje rezoliucijoje kviete , it vieningą darbą ir ryžtingą kovą už Lietuvos nepriklausomybę ir tautos gyvybę visas tas lietuvių grupes, organizacijas, kurios šiame mūsų tautos sukrètime pasiliko lietuvių tautai ištikimos "77. Be to, rezoliucijoje pabrěžta, kad „bendroj taryboj ar centre bus dirbami tiktai tie darbai, kurie turès aiškų ryši su darbais ir kovomis už laisvą ir nepriklausomą Lietuvą" ${ }^{\text {“8 }}$. Vadinasi, nebus kišamasi į bendrą centrą įeinančių grupių vidaus reikalus. ALRKF, pritardama paskelbtai LGT nuostatai dèl būsimos Lietuvos santvarkos, dar papildè: „Atstatyti Lietuvos valstybę demokratiniais pagrindais, aiškiai užbrèžtais Lietuvos Nepriklausomybès Deklaracijoj, paskelbtoj 1918 m. vasario 16 d. ir Lietuvos konstitucijoj, priimtoj Steigiamajame Seime ${ }^{\text {‘9 }}$.

Naujają organizaciją pasveikino Lietuvos Respublikos ministras Vašingtone Povilas Žadeikis: „Lietuvai gelbèti tarybos sudarymas Amerikoje yra tinkamiausias ir realus Amerikos lietuvių protestas ir atsakymas Lietuvos okupantams “10. LGT iškèlè tikslą palaikyti glaudų ryši su užsienyje veikiančia nepriklausomos Lietuvos vyriausybe arba

Ten pat.

6 Skirius, J., Račkauskas, J. Amerikos lietuviu tarybos kūrimosi 1939-1941 metais atspindžiai dokumentuose ir spaudoje. Chicago, 1998, p. 105.

7 Federacijos tarybos suvažiavimo rezoliucijos. Draugas. 1940, rugpjūčio 14; Skirius, J., Račkauskas, J. Amerikos lietuviu tarybos kūrimosi 1939-1941 metais atspindžiai dokumentuose ir spaudoje. Chicago, 1998, p. 100; P. Daužvardžio 1940 m. liepos 23 d. laiškas P. Žadeikiui. Lietuvos centrinis valstybès archyvas (toliau - LCVA). F. 656, ap. 2, b. 678, lap. 1.

8 Skirius, J., Račkauskas, J. Amerikos lietuviu tarybos kūrimosi 1939-1941 metais atspindžiai dokumentuose ir spaudoje. Chicago, 1998, p. 139.

9 Konferencijos nutarimai. Draugas. 1940, spalio 29; Skirius, J., Račkauskas, J. Amerikos lietuviu tarybos kūrimosi 1939-1941 metais atspindžiai dokumentuose ir spaudoje. Chicago, 1998, p. 139.

${ }^{10}$ P. Žadeikio 1940 m. rugpjūčio 5 d. laiškas P. Grigaičiui. LCVA. F. 656, ap. 2, b. 678, lap. 4. 
jos atstovais. Po katalikų derybų su sandariečiu ir tautininkų grupių atstovais buvo sudaryta centro valdžia, kurios pirmininku tapo L. Šimutis, sekretoriumi - tautininkas Kazys Karpius ${ }^{11}$. Veiklos planuose buvo numatyta: užmegzti ryšius su JAV valdžios institucijomis, palaikyti santykius ,su laisvès ir nepriklausomybès siekiančia Lietuvos visuomene", rengti memorandumus ir pareiškimus, informuojant JAV ir užsienio spaudą apie Lietuvą ir jos laisvinimo labui nuveiktus darbus, skelbti šią medžiagą ir lietuvių spaudoje $\mathrm{e}^{12}$.

Netrukus prie LGT prisijungè ir socialistai. Prisijungima jie motyvavo taip: „Mes labai susilpnintume savo poziciją, jeigu nepasisakytume, kad stojame už nepriklausomą ir demokratinę Lietuvą “13. Tokiam apsisprendimui, o ir apskritai visam JAV lietuvių vienijimuisi itakos turejjo diplomato P. Žadeikio pozicija: „Lietuvos nepriklausomybès vadavimo idèja daug laimètu̧, jeigu Amerikos lietuvių trys didžiausiosios srovès sudarytų bendrą Tarybą sutartiniams žygiams atlikti [...] nepriklausomybès gelbèjimo idèja daug nukentètu, jei srovès nerastų reikalo bendrai dirbti“"14.

Tolesniam LGT stiprejimui ir pripažinimui buvo reikšmingas jos delegacijos prièmimas Baltuosiuose rūmuose. $1940 \mathrm{~m}$. spalio $15 \mathrm{~d}$. lietuvių kataliku̧, socialistų ir tautininkų atstovus, vadovaujamus L. Šimučio, prièmė JAV prezidentas Franklinas D. Ruzveltas (Franklin D. Roosevelt). LGT iteiktame memorandume buvo pasveikintas $1940 \mathrm{~m}$. liepos 23 d. pareiškimas dèl Baltijos šalių okupacijos ir pažymėta, kad JAV prezidentas yra teisingumo pusèje ir jis , „žiebs Lietuvos viltị užimti jos vietą tarp laisvų Žemės tautų “15. I tai F. D. Ruzveltas atsakè: „Lietuva nepriklausomybès neprarado - Lietuvos nepriklausomybė tik laikinai pertraukta (suspenduota). Ateis laikas ir Lietuva vèl bus laisva. Tai atsitiks gal greičiau, negu jūs galite tikètis"16. Toks JAV prezidento patikinimas kèlè lietuvių pasitikèjimą savo jègomis ir skatino jungtis į Lietuvos laisvinimo procesą, kuris, atrodè, neturètų užtrukti.

Po šio susitikimo LGT paskelbẻ pareiškimą, kuriame išreikẻ pasiryžimą , dirbti, kurti ir kovoti visomis teisètomis priemonèmis, kad Lietuva vèl taptų laisva, nepriklausoma valstybe “117. Išeiviai aiškiai akcentavo, kad atkurtoji Lietuva bus demokratinè, ,atsteigta $1918 \mathrm{~m}$. vasario $16 \mathrm{~d}$. deklaracijos Vilniuje nužymètais dèsniais ${ }^{\text {“18 }}$. Taip pat LGT

${ }^{11}$ Dèl bendro veikimo. Draugas. 1940, rugpjūčio 15; Skirius, J., Račkauskas, J. Amerikos lietuviu tarybos kūrimosi 1939-1941 metais atspindžiai dokumentuose ir spaudoje. Chicago, 1998, p. 103.

${ }_{12}$ Lietuvai gelbèti taryba. LCVA. F. 656, ap. 2, b. 678, lap. 6-7.

${ }_{13}$ P. Grigaičio 1940 m. rugsèjo 1 d. laiškas P. Žadeikiui. LCVA. F. 656, ap. 2, b. 678, lap. 16.

${ }^{14}$ P. Žadeikio 1940 m. rugpjūčio 15 d. laiškas P. Grigaičiui. LCVA. F. 656, ap. 2, b. 678, lap. 13.

15 Šimutis, L. Amerikos lietuviu taryba: 30 metu Lietuvos laisvès kovoje 1940-1970. Chicago, 1971, p. 458.

${ }^{16}$ Ten pat, p. 25; Amerikos lietuviu istorija. Bostonas, 1971, p. 552.

${ }^{17}$ LG Tarybos pasisakymas. Draugas. 1940, spalio 19; Skirius, J., Račkauskas, J. Amerikos lietuviu tarybos kūrimosi 1939-1941 metais atspindžiai dokumentuose ir spaudoje. Chicago, 1998, p. 131; Šimutis, L. Amerikos lietuviu taryba: 30 metu Lietuvos laisvés kovoje 1940-1970. Chicago, 1971, p. 34.

${ }^{18}$ Ten pat. 
kviete i politinę veiklą tas JAV lietuvių organizacijas, „kurios aiškiai stovi už laisvą ir nepriklausomą Lietuvą ir derins išeivijos visuomenès tautinę veiklą Lietuvos nepriklausomybei atsteigti“"19. Be to, dokumente skatinama Europoje šiam tikslui įsteigti Lietuvos vyriausiaji komitetą ir jam pažadèta visokeriopa parama. Tačiau $1941 \mathrm{~m}$. lapkričio 3 d. Čikagoje įvykęs diplomato P. Žadeikio surengtas Prezidento A. Smetonos susitikimas su ALT pirmininku paneige šios idejos igyvendinimo galimybę. Prieš tai pasisakè tiek Prezidentas, tiek P. Žadeikis ${ }^{20}$.

Po Vašingtone ịvykusio susitikimo pagausèjo LGT gretos - prie ALRKF prisišliejusių Amerikos lietuvių sandaros (toliau - ALS), Amerikos lietuvių tautinès sajungos (toliau - ALTS) ir Amerikos lietuvių socialdemokratų sajungos (toliau - ALSS) dabar jungèsi dar du susivienijimai-ALRKS ir Susivienijimas lietuvių Amerikoje (toliau - SLA). Taip buvo igyvendintas sumanymas JAV mastu sudaryti bendrą lietuvių išeivių Lietuvos laisvinimo organizaciją. 1941 m. gegužès 15 d., minint Steigiamojo Seimo sukakti, LGT Centro valdyba nusprendẻ keisti organizacijos pavadinimą $i$ Amerikos lietuvių tarybą. Iškilusi ALT tęsè pradètus darbus ir „Amerikos lietuvių visuomenès daugumos nepalaužiamą pasiryžimą dirbti ir kovoti, kad Lietuva būtų išvaduota iš bolševikinès Rusijos okupacijos ir būtų atsteigta kaip nepriklausoma, demokratinè valstybė jai priklausančiose ribose ${ }^{621}$. ALT, patvirtindama ankstesnę LGT nuostata, nurodè, kad atkurtos valstybès santvarka bus ,paremta tais demokratybès dèsniais, kurie buvo paskelbti $1918 \mathrm{~m}$. vasario $16 \mathrm{~d}$. deklaracijoje ir buvo inkorporuoti i Lietuvos steigiamojo seimo priimtą Respublikos konstituciją ${ }^{\text {“22 }}$. Vadinasi, minint Steigiamojo Seimo sukaktį, ALT skelbė siekius išlaisvinto krašto gyvenimą tvarkyti pagal $1922 \mathrm{~m}$. Konstitucija, tai yra pagal parlamentinès respublikos modeli. Be to, Lietuvos laisvinimo veiklą numatyta derinti su Vakarų demokratijomis, kovojančiomis prieš ,totalitarines diktatūras". Šią nuostatą formavo ir tas faktas, kad tuo metu JAV ir Didžioji Britanija nepripažino Pabaltijo inkorporavimo į Sovietų Sajungą. Be to, itakos turèjo tiek kataliku, tiek socialistų buvimas demokratijos pusėje. Pavyzdžiui, ALSS pasisakẻ už rinkimų teise, o buvusią Lietuvos santvarką ịvertino šitaip: ,,[...] Smetona 1926 metais visa tai sutrempe ir per 14 metu jokioms politinems partijoms nedavé teisiu, tik saviem neva tautininkam“23. Tačiau dabar, pasak socialistų, kai Lietuvą ištiko katastrofa, būtina politinių srovių vienybė ir sveikintina katalikų pozicija sprendžiant Lietuvos santvarkos klausimą,,Smetonos reikalą "laikyti ,,asmeniniu reikalu“. Vadinasi, jie, likdami priešiški

${ }^{19}$ Ten pat.

${ }^{20}$ Ten pat.

${ }^{21}$ Tarybos pareiškimas Lietuvos reikalais. Draugas. 1941, gegužès 17; Skirius, J., Račkauskas, J. Amerikos lietuviu tarybos kūrimosi 1939-1941 metais atspindžiai dokumentuose ir spaudoje. Chicago, 1998, p. 177.

22 Ten pat.

${ }^{23}$ LSS reikalai. Naujoji Gadyne. 1941, vasario 20; Skirius, J., Račkauskas, J. Amerikos lietuviu tarybos kūrimosi 1939-1941 metais atspindžiai dokumentuose ir spaudoje. Chicago, 1998, p. 169. 
„Smetonai ir smetonininkams“, ne tik nepriekaištavo dèl tokios pozicijos katalikams, bet ir siūlè panašiai elgtis tautininkams ir keisti savo nuostatas ${ }^{24}$.

Tačiau dèl socialistų ir katalikų neigiamo požiūrio į A. Smetoną, ALTS nutraukẻ ryšius su ALT ir $1941 \mathrm{~m}$. birželio $7 \mathrm{~d}$. issteigè Lietuvai vaduoti sajungą (LVS), kurios centrine figūra tapo i JAV atvykęs Prezidentas A. Smetona. Organizacija buvo sukurta garsiojoje Tabor Farmoje (jos šeimininkas - žymus JAV lietuvis, tautininkas Juozas J. Bačiūnas, pas kuri tuomet laikinai buvo apsistojęs A. Smetona). Tautininkai manė, kad Lietuvos laisvinimo veikla JAV turètų būti formuojama dviem kryptimis - reikètų veikti tarp lietuvių ir tarp amerikiečių. Pirmuoju atveju būtina lietuvius nuosekliai informuoti ir raginti jungtis $\mathfrak{i}$ Lietuvos bylos gynimą. Lietuvos laisvès klausimą keliant tarp amerikiečiu, LVS manymu, tinkamiausias asmuo esąs Prezidentas A. Smetona. JAV lietuviai, nepaisydami priešiško kai kurių veikèjų nusistatymo, ji ,aukštai vertino“, o tarp amerikiečiu , jis tiesiog buvo gerbiamas, kaip ilgametis Lietuvos prezidentas ${ }^{\text {“25. }}$. Taip paaiškinamas greitas LVS iškilimas ir išpopuliarejimas. Tačiau tragiška naujosios sajungos $1944 \mathrm{~m}$. sausio $9 \mathrm{~d}$. lemtis koregavo jos veiklą, ir tų metų vasario 5-6 d. Niujorke vykęs LVS seimas sudare Amerikos Lietuvių misiją ${ }^{26}$. Ši organizacija ėmè toliau rūpintis Lietuvos laisvinimo reikalų propagavimu JAV. Taip Amerikoje atsirado ALT oponentè, kuri irgi pasiryžo jungti tautiečius Lietuvos laisvès ir nepriklausomybès darbams. Tuo metu ALT tobulino valdymą ir išrinko Vykdomaji komitetą (VK). I ji iejjo trys nariai: pirmininku patvirtintas L. Šimutis (katalikiškosios srovès atstovas), sekretoriumi - Pijus Grigaitis (socialdemokratas), iždininku paskirtas Mykolas Vaidyla (sandarietis). Prasidejus SSRS ir Vokietijos karui, ALT daug dèmesio skyre Lietuvos ir lietuvių šelpimo organizavimui. Svarstant politinio pobūdžio problemas, buvo pabrěžiama būtinybẻ ikurti Lietuvos informacijos biurą. Todèl šie du klausimai ilgą laiką vykstant karui išliko darbotvarkèje.

1941-aisiais Lietuvoje žlugus Laikinajai vyriausybei, ALT iškẻlè idèją sudaryti egzilinę vyriausybę ir bandè ją igyvendinti. $1941 \mathrm{~m}$. lapkričio 3 d. diplomato P. Žadeikio iniciatyva Čikagoje, dalyvaujant ALT pirmininkui L. Šimučiui, surengtas susitikimas su A. Smetona. Jame L. Šimutis supažindino su egzilinès vyriausybès, kurios priešakyje būtų A. Smetona, sudarymo idèja. Nors šiam sumanymui buvęs Prezidentas pritarè, P. Žadeikis tokiai minčiai prieštaravo ${ }^{27}$. Kita vertus, praslinkus mènesiui (gruodžio 18 d.) Lietuvos pasiuntinys P. Žadeikis šiuo klausimu teiravosi JAV Valstybės departamente, čia buvo pasiūlyta atidèti toki sprendimąe ${ }^{28}$.

ALT, neatsisakydama minties stiprinti Lietuvos reikalų centrą, $1943 \mathrm{~m}$. rugsejjo

${ }^{24}$ Ten pat.

${ }^{25}$ Amerikos lietuviu misija ir jos darbai. Detroit, 1945, p. 6.

${ }^{26}$ Skirius, J. Amerikos lietuviu tarybos veikla 1945-1948 metais: išeivijos pastangos dèl 'Displaced Persons Act' priemimo. Chicago, 2001, p. 75.

27 Šimutis, L. Amerikos lietuviu taryba: 30 metu Lietuvos laisvés kovoje 1940-1970. Chicago, 1971, p. 35.

${ }_{28}$ Jonušauskas, L. Likimo vedami: Lietuvos diplomatines tarnybos egzilyje veikla 1940-1991. Vilnius, 2003, p. 124. 
2-3 dienomis Pitsburge sušaukè pirmaji Amerikos lietuvių kongresą. Jame aptariant politinès krypties darbus buvo pažymèta, kad bus toliau remiami Vakarų demokratinių kraštų karo tikslai ir reikalaujama taikyti Lietuvai 1941 m. rugpjūčio 14 d. JAV prezidento F. D. Ruzvelto ir Didžiosios Britanijos premjero Vinstono Čerčilio (Winston Churchill) paskelbtą Atlanto Chartiją. Kaip žinoma, šis dokumentas konstatavo pasaulio sutvarkymo, pasibaigus karui, principus. Suvažiavime dar kartąpatvirtintas JAV lietuvių tikslas - atkurti Lietuvos nepriklausomą demokratinę valstybę $e^{29}$.

Išlaikydama nuoseklumą Lietuvos laisvinimo procese ir pasinaudodama didžiujų valstybiu, dalyvaujančių kare prieš nacių Vokietija, atstovų susitikimu proga, ALT nepamiršdavo priminti Lietuvos laisvės reikalų. Pavyzdžiui, 1943 m. vykstant JAV ir Didžiosios Britanijos užsieniųreikalųministrų susitikimui, JAV prezidentui F. D. Ruzveltui ALT pasiuntė telegrama, kurioje išreiškè vilti, kad aneksuotieji Baltijos kraštai, padedant Vakarų demokratijoms, atkurs nepriklausomybę ir laisvę ${ }^{30}$. Dar vieną telegramą ALT parengè JAV valstybès departamentui. Joje buvo nuogąstaujama dèl 1943 m. lapkriti Maskvoje vykusioje sajungininkų užsienio reikalų ministrų konferencijoje nepalankiai svarstyto Baltijos valstybių klausimo ir išreikštos: ,tos pesimistiškos nuostatos, kurios apėmé dalį mūsų visuomenès po Maskvos konferencijos ${ }^{\text {“31 }}$. Gautame atsakyme buvo patikinta, kad JAV politika tiek Baltijos, tiek Lietuvos atžvilgiu nèra pakitusi ${ }^{32}$.

ALT, stebėdama sajungininkams palankia linkme krypstančią padètį kare ir likdama ištikima Atlanto Chartijos principams, 1944 m. apibrěżè lietuvių siekius: „Juk mums visiems rūpi, kad, kaip viso pasaulio žmonès, taip ir Lietuvos žmonès, turi turèti laisvę kalbèti, laisvę rašyti, laisvę tikèti, gyventi be baimès, be vargo, tiek savo vidaus tvarka, tiek tarptautine prasme, tiek paskiram asmeniui, tiek valstybiniam junginiui. Kiek mūsų isteigtam centrui, tiek visam mūsų darbui gyva inspiracija yra garbinguose Atlanto Čarterio dèsniuose ${ }^{\text {“33 }}$.

Baigiantis Antrajam pasauliniam karui, 1945-ujų pradžioje San Franciske susirinkusios 50 valstybių delegacijos ịkūrẻ Jungtinių Tautų Organizaciją (JTO). I šią steigiamają konferenciją stebėtojų teisèmis delegacijąnusiuntè ir JAV lietuviai. Tačiau esant dviem politiniams dariniams, kurie JAV rūpinosi Lietuvos laisvès atkūrimu, nuvyko dvi delegacijos. Vieną jų sudare ALT nariai, o kitą - ALM. Tai atspindejjo ne tik lietuvių išeivijos susiskaldymą, bet ir demonstravo jų politini nebrandumą ir nesugebejjimą susitarti esminiu visai išeivijai klausimu - Lietuvos laisvinimo vizija ${ }^{34}$.

Permainingame tarptautinių ivvykių sūkuryje $1945 \mathrm{~m}$. lapkričio 29-gruodžio $1 \mathrm{~d}$. Čikagoje buvo sušauktas antrasis Amerikos lietuvių kongresas. Jame buvo patobulintas

29 Šimutis, L. Amerikos lietuviu taryba: 30 metu Lietuvos laisvès kovoje 1940-1970. Chicago, 1971, p. 48.

${ }^{30}$ Ten pat, p. 474.

${ }^{31}$ ALT VK pranešimas spaudai, 1943 m. LCVA. F. 656, ap. 2, b. 678, lap. 46.

32 Šimutis, L. Amerikos lietuviu taryba: 30 metu Lietuvos laisvès kovoje 1940-1970. Chicago, 1971, p. 50.

33 ALT darbai. Draugas. 1944, gegužès 16(?) (iškarpa); LCVA. F. 656, ap. 2, b. 678, lap. 22-24.

34 Šimutis, L. Amerikos lietuviu taryba: 30 metu Lietuvos laisvès kovoje 1940-1970. Chicago, 1971, p. 81. 
ALT statutas, kuriame atspindèti keturi svarbiausi organizacijos tikslai. Pirmasis skelbė: „Jungti visas Amerikos lietuvių demokratines jègas kovai už pagrindines žmogaus asmens teises ir už pasaulio pastangas, siekiant pastovios taikos, pagristos teisingumo, demokratijos ir laisvès pagrindais ${ }^{\text {“35 }}$. Antrasis: siekti, kad Lietuvai būtų taikomi ir igyvendinti Atlanto Chartijos principai - atkurta jos nepriklausomybė su istorinèmis etnografinèmis sienomis, atsižvelgiant $i$,,reikalingas geografines ir ekonomines korektyvas“". Trečiasis: teikti moralinę ir materialinę paramą Lietuvos žmonèms, kovojantiems už laisvę, šelpti politinius pabėgèlius ir tremtinius. Ketvirtasis: skleisti visuomenei teisingą informaciją apie Lietuvą ir ginti ją nuo prasimanymų. Priimtoji kongreso rezoliucija buvo skirta JAV oficialios valdžios institucijoms ir, reiškiant nekintamą lietuvių tautos valią, prašyta paramos atkuriant nepriklausomą Lietuvos valstybę. Tokius tikslus kèlè ALT, tikèdamasi, kad artimiausiu metu įvyks didžiuju valstybių karo sajungininkų derybos.

Susiklosčius komplikuotoms tarptautinėms aplinkybėms, 1946 m. rugsėjo 21-22 dienomis Vašingtone įvyko ALT metinis suvažiavimas. Svarstant Lietuvos laisvinimo problemą, buvo užsibrež̌ta ryžtingai veikti politiniame bei visuomeniniame gyvenime ir bendradarbiauti su Vyriausiuoju Lietuvos išlaisvinimo komitetu ${ }^{36}$. Siekiant užtikrinti Lietuvos laisvinimo finansavima, buvo nutarta kaupti lěšas ir per pusmetį surinkti ketvirti milijono dolerių. Suvažiavimo rezoliucijoje pažymèta, kad ALT ,nutare išplèsti ir padauginti savo pastangas, talkininkaujant vyriausybei jos pastangose teisingai taikai igyvendinti, moraliai gelbèti Lietuvos žmonèms tèvynei laisvę, nepriklausomybę ir demokratiją atsteigti ${ }^{\text {“637. }}$.

Naujuoju JAV prezidentu tapus Hariui S. Trumanui (Harry S. Truman), ALT ryžosi išsiaiškinti dabartinę JAV politiką okupuotu Baltijos šalių atžvilgiu. Todèl ruošiantis galimam susitikimui Baltuosiuose rūmuose ALT numatè vadovautis tokiomis nuostatomis: pirma, pasiūlyti JAV vyriausybei talkinti igyvendinant Atlanto Chartijos principus; antra, padèkoti JAV už Baltijos šalių aneksijos nepripažinimo tęsimąir Baltijos tremtinių „simpatingą traktavimą“; trečia, išsiaiškinti JAV poziciją dèl SSRS pretenzijų i Koenigsbergo sriti; ketvirta, patikrinti, ar JAV laikosi D. F. Ruzvelto pozicijos, išsakytos 1940 m. spalio 15 d., bei Valstybės departamento 1940 m. liepos 23 d. išreikšto požiürio i Baltijos kraštuose vykstančius procesus ${ }^{38}$. Netrukus, $1946 \mathrm{~m}$. spalio $29 \mathrm{~d}$., sulaukta audiencijos ir vienuolikos ALT narių delegacija, vadovaujama L. Šimučio, nuvyko i Baltuosius rūmus. Pirmiausia buvo įteiktas memorandumas, kuriame išdėstyti Lietuvos nepriklausomybès lūkesčiai ir iškeltas lietuvių karo pabėgèlių ịkurdinimo klausimas. Atsakydamas JAV prezidentas H. S. Trumanas patikino, kad ,stengiasi parūpinti ịva-

35 Amerikos lietuviu taryba. Chicago, 1952, p. 2.

${ }^{36}$ ALT 1946 m. rugpjūčio 29 d. raštas. LCVA. F. 656, ap. 2, b. 678, lap. 99.

${ }^{37}$ LAIC. Žinių santrauka, 1946 m. rugsèjo 28 d. LCVA. F. 656, ap. 2, b. 1049, lap. 168; ALT metinis suvažiavimas. LCVA. F. 656, ap. 2, b. 1049, lap. 175-177.

${ }^{38}$ P. Žadeikio 1946 m. rugsèjo 12 d. raštas P. Daužvardžiui. LCVA. F. 656, ap. 2, b. 678, lap. 105. 
žiavimą DP 39 “ ir prašysiąs Kongreso papildyti imigracijos isstatymą. Be to, prezidentas patvirtino, kad JAV politika dèl Baltijos valstybių okupacijos „,nepasikeitè ir negalinti pasikeisti“. Pasak jo, JAV sieks, kad ,taikos problemos būtų išreikštos taikiu būdu, be kovojimo, nes jei nepavyktų išreikšti, tai būtų kova. Niekas iš mūsų nenori, kad būtų kovojama ${ }^{640}$. Viena vertus, nors ir nebuvo pažadèta imtis konkrečių veiksmų dèl Lietuvos sovietinès okupacijos panaikinimo, šis susitikimas patvirtino JAV politikos Baltijos šalių atžvilgiu tęstinumą. Kita vertus, tapo aišku, kad Lietuvos laisvinimo procesas užsitęs. Tačiau būta palankių lietuviams ženklų tarptautiniu mastu. Sprendžiant DP Vokietijoje problemą pasitarnavo JAV delegatès JTO Eleonoros Ruzvelt pareiškimas, paskelbtas $1946 \mathrm{~m}$. lapkričio $8 \mathrm{~d}$. Ji, paminėdama lietuvius, latvius, estus, pareiškè, kad JAV jokiu būdu neleis sovietams grą̌inti i Rusiją tremtinius, kurie atsisako grįžti i okupuotus kraštus ${ }^{41}$.

Penktojo dešimtmečio viduryje Amerikoje veikè dvi organizacijos, pasiryžusios kelti Lietuvos laisvès byla, - ALT ir ALM. Tuometinių Lietuvos diplomatų vertinimu, pirmoji,,statosi lyg ir oficialiais žmonėmis ir remiasi ant memorandumu“", antroji ,skaitosi tik Lietuvos draugais ir remiasi visuomenès opinijos kẻlimu Lietuvos naudai“‘放. Šios organizacijos veikè tarsi viena kitą papildydamos, tačiau efektyvinant Lietuvos laisvinimo procesą buvo svarbu vienyti pajègas. Tuo tikslu ALT pakvietė sugrižti i savo gretas tautininkų grupę. Tokią idèją ALT kèlè dar $1945 \mathrm{~m}$., tuomet LVS atsakè: „Mes siekiame nepriklausomos Lietuvos atkūrimo, tat jei jums tarybininkams (ALT nariams - autoriaus pastaba) tas tikslas yra priimtinas, istokite į Lietuvai vaduoti Sajungą ir įvyks vienybé ${ }^{\text {‘43 }}$. Tarp ALT ir tautininkų takoskyra atsirado dèl skirtingo požiūrio i Lietuvos santvarką 1926-1940 m. ir 1938 m. Konstituciją. Vienas JAV tautininkų lyderių Julius Smetona $1945 \mathrm{~m}$. kovo 24 d. išreiške šios srovès pozicijas, paremtas VLIK`o 1944 m. vasario 16 d. paskelbtu atsišaukimu ,I Lietuvių tautą“. Y pač pabrèžtas trečias straipsnis, kuriame teigiama, kad „Lietuvą iš okupacijos išlaisvinus ir toliau veikia 1938 m. Lietuvos konstitucija, kol ji teisètu būdu nebus atitinkamai pakeista“"“44. Taip buvo patvirtinta, kad bus vykdomas teisinis Lietuvos valstybės „,kontinuitetas“ ir siekiama prezidentinès respublikos modelio. Todèl tautininkai, pritardami VLIK'ui, tvirtino, kad tokia nuostata ,turi būti visų mūsų kovos už Lietuvos laisvę pagrindas““45.

${ }^{39}$ DP - Displaced Persons, liet. ,perkeltieji asmenys“. Po Antrojo pasaulinio karo Vokietijoje ikurtos pabėgèliu stovyklos. Redaktoriaus pastaba.

${ }^{40}$ ALT pro memoria, 1949 m. spalio 29 d. LCVA. F. 656, ap. 2, b. 678, lap. 109; President Truman reaffirms American Baltic policy. Lithuanian bulletin. 1946, Nr. 3, p. 2.

${ }^{41}$ ALT biuletenis, 1983. LCVA. F. 656, ap. 2, b. 678, lap. 262.

42 P. Daužvaidžio 1946 m. liepos 17 d. laiškas P. Žadeikiui. LCVA. F. 656, ap. 2, b. 678, lap. 82.

${ }^{43}$ Smetona, J. Keletas minčiu svarbiu klausimu. Dirva. 1945, liepos 20 (iškarpa); LCVA. F. 656, ap. 2, b. 680 , lap. 68 .

${ }^{44}$ Amerikos lietuviu misija ir jos darbai. Detroit, 1945, p. 19.

${ }^{45}$ Ten pat. 
Be to, ALT pasisakè už galimą išlaisvintų valstybių federaciją arba konfederaciją, o LVS liko šių darinių priešininku.

Dar 1946-aisiais VLIK`o pirmininkas Mykolas Krupavičius kreipėsi i ALM ir ju priešaky esančius tautininkus, ragindamas puoselèti JAV lietuvių patriotinių pajègų vienybę. Jis teigè: „Mums neatrodo, kad esminių skirtumų tarp Amerikos patriotinių grupių dèl kuriųnebūtų imanoma dirbti dèl Lietuvos laisvès, dẻl demokratinès Lietuvos. O neesminiai skirtumai nèra nenugalimi. Dẻl to su visu nuoširdumu kviečiame palikti nuošaliai neesminius skirtumus ir ịsijungti į bendrą Amerikos lietuvių tarybos darbą. Vardan tos Lietuvos vienybė težydi“‘46. Vis tik lemtingas žingsnis vienijimosi linkme buvo žengtas $1947 \mathrm{~m}$. lapkričio 7 d. Niujorke, kai ALT igaliotiniai, dalyvaujant diplomatui P. Daužvardžiui ir VLIK'o nariui P. Padalskiui, susitiko su tautininkų atstovais. Pastarieji patikino, kad pasiūlymą vienytis priima be jokių išankstinių sąlygư ${ }^{47}$. Tai sudarè prielaidas panaikinti tautininkų sukurtą paralelinę ALT organizaciją ir ištrynė takoskyrą, skyrusią JAV lietuvių patriotines pajègas.

1948 m. buvo paženklinti ALT vienijimosi sẻkmės. Sausio 11-ają ìvykusiame Pitsburgo suvažiavime tautininkai sugrižo į ALT, o jų atstovas Antanas Olis tapo VK vicepirmininku. Tais pačiais metais paskelbtame ALT statute itvirtinama išlaisvintos Lietuvos vizija, kuriai pritare visos JAV lietuvių patriotinès pajègos. Vengiant prieštaravimų tarp partinių srovių dokumente teigiama, esą bus siekiama, kad „Atlanto Chartos dėsniai būtų pritaikyti Lietuvai, atsteigiant jos nepriklausomybę istoriškai etnografinėse sienose, su reikalingais geografiniais korektyvais ${ }^{{ }^{448}}$. Be to, patvirtinama, kad ALT sudaro JAV lietuvių organizacijos, kurios ,stovi už nepriklausomos demokratinès Lietuvos Respublikos atstatyma, pripažista demokratinius principus ir juos vykdo gyvenime“"49. Tokiu būdu ALT, vèl suvienijusi keturias politines ideologines išeivijos grupes, itvirtino aiškią Lietuvos laisvinimo veiklos ir būsimos nepriklausomos valstybès viziją - demokratinę respubliką. Vis dèlto, vengiant grupių nesutarimų konkreti konstitucija, pagal kurią išsilaisvinusi Lietuva tvarkytųsi, nebuvo minima.

Dar viena ALT politinès veiklos naujovė - JAV prezidento rinkimų kampaniju panaudojimas Lietuvos labui. Tiek respublikonu̧, tiek demokratų partijų kandidatams buvo įteikti memorandumai, kuriuose išreikšti lietuvių tautos siekiai. Apeliuodama i Atlanto Chartijos ir JTO deklaracijas, ALT būsimiems JAV prezidentams išdèstė ir priminè savo reikalavimus: pirmiausia pabrèžè, kad Lietuva yra neteisètai sovietų užgrobta ir JAV šio jungimo nepripažissta. Toliau pateikẻ laisvinimo gaires, kuriose JAV paprašė: viešai ir griežtai pasmerkti SSRS okupuotose kraštuose vykdomą gyventojų žudymą ir naikinimą; inicijuoti JTO reikalavimą atkurti Lietuvos ir kitų Baltijos kraštu

\footnotetext{
46 Šimutis, L. Amerikos lietuviu taryba: 30 metu Lietuvos laisvès kovoje 1940-1970. Chicago, 1971, p. 93.

${ }^{47}$ Ten pat.

${ }^{48}$ ALT statutas. Chicago, 1948, p. 2.

49 Ten pat.
} 
suverenumą; nepasirašyti su sovietais jokių sutarčių ribojančių Baltijos tautų galimybes atgauti laisvę ir nepriklausomybę ${ }^{50}$.

Ivardytuose reikalavimuose atsispindèjo tuometinè ALT Lietuvos laisvinimo programa. Jos pagrindas buvo JAV politikos dèl Baltijos šalių inkorporavimo nepripažinimo tęsimas ir dar gilus pasitikèjimas pasaulinès organizacijos - JTO - galiomis. Tokia programa - penktajam ir šeštajam dešimtmečiams būdingas Lietuvos laisvinimo proceso bruožas.

1948 m. rugsejjo 16 d. įvyko dar viena audiencija Baltuosiuose rūmuose. Šikart ALT delegaciją sudarè: L. Šimutis, P. Grigaitis, M. Vaidyla, Povilas Dargis ir Jonas Grigalius. Jų memorandume, iteiktame prezidentui H. S. Trumanui, išreikštas pageidavimas, kad Paryžiuje vyksiančioje JTO asamblèjoje JAV delegacija iškeltų okupuotų Baltijos šalių padèties klausima. Be to, ALT paprašè, kad JAV nepasirašytų Taikos sutarties, kol nebus išlaisvinta Lietuva ir kitos okupuotos šalys ${ }^{51}$. Nors šis susitikimas Baltuosiuose rūmuose nežadejo greitų poslinkiųLietuvos laisvinimo procese, bet pasitarnavo garsinant Lietuvos ir kitų Baltijos šalių laisvès bylą Amerikoje.

Tolesnès Lietuvos laisvinimo gairès buvo nubrèžtos trečiajame Amerikos lietuvių kongrese, kuris vyko 1949 m. lapkričio 4-6 dienomis Niujorke. Kongresas, išreikšdamas pavergtos lietuvių tautos lūkesčius, pagrindinèje deklaracijoje akcentavo sovietųpuolimą prieš Vakarų krikščioniškosios kultūros kraštus ir žmogaus teisių nepaisymą, religijos persekiojimą sovietų užgrobtuose kraštuose. JAV vyriausybė paraginta anuliuoti in toto neratifikuotus Teherano, Jaltos ir Potsdamo konferenciju politinius sprendimus, nes pastarieji negalioja dèl SSRS nusižengimų isipareigojimams. Kongreso dalyviai tikejjosi JAV patvirtinimo, kad taika bus atkuriama laikantis Atlanto Chartijos principų. Be to, jų manymu, JAV turètu primygtinai reikalauti ,šventos pareigos“ dèl sutarčiu, kurias SSRS 1920-1938 metais pasirašè su Estija, Latvija, Lietuva, ir sovietų karinių pajègu išvedimo iš šių valstybių. Taip pat JAV turètų atkreipti dèmesi $\mathfrak{i}$,,rusų okupuotose Baltijos valstybėse ir tariamai suverenioje Ukrainoje" vykstančias ginkluotas kovas, kurios pertraukia ,tarptautinès taikos ir saugumo gijas ${ }^{\text {“52 }}$. Deklaracijoje išreikšta viltis, kad JAV, vadovaudamasi $1940 \mathrm{~m}$. liepos $23 \mathrm{~d}$. pareiškime suformuluotomis nuostatomis, sustabdys sovietų vyriausybès vykdomą genocidą ${ }^{53}$. Kaip matyti, deklaracija buvo paremta tarptautiniais dokumentais ir tvirtai bei įtikinamai grindė Lietuvos nepriklausomybès atgavimo kelią.

\footnotetext{
${ }^{50}$ Ten pat.

${ }^{51}$ Šimutis, L. Amerikos lietuviu taryba: 30 metu Lietuvos laisvès kovoje 1940-1970. Chicago, 1971, p. 98.

${ }_{52}$ Ten pat, p. 481.

${ }_{53}$ Ten pat.
} 


\section{Išvados}

1. XX a. penktajame dešimtmetyje prasidèjus Lietuvos ir kitų Baltijos valstybių okupacijai, senoji JAV lietuviu išeivija pirmoji Vakaruose èmési ginti Lietuvos nepriklausomybę ir laisvę. $1940 \mathrm{~m}$. rugpjūčio $10 \mathrm{~d}$. Pitsburge svarbiausios lietuvių politinès organizacijos, paragintos Amerikos lietuvių Rymo katalikų federacijos, isteigė Lietuvai gelbèti tarybą. Tai buvo pirmoji lietuvių rezistencinès kovos su sovietu okupantu organizacija. $1940 \mathrm{~m}$. spalio $15 \mathrm{~d}$. LGT delegacijos prièmimo Baltuosiuose rūmuose metu JAV prezidentas F. D. Ruzveltas ištare istorinę frazę apie Lietuvos nepriklausomybės suspendavimą, o tai Vakaruose gyvenantiems lietuviams suteikè naujų impulsų politinei veiklai.

2. Išeivių organizacijos nevienodai ižvelgè būsimos Lietuvos konstitucinę santvarką ir parlamentarizmo galimybę:

2.1. LGT, pasipildžiusi naujomis pajègomis ir sujungusi pagrindines JAV lietuvių politines sroves, - katalikus, socialistus, sandariečius ir tautininkus, $1941 \mathrm{~m}$. gegužès 15 d. sudare Amerikos lietuvių tarybą. Pagrindiniu savo uždaviniu ALT iškẻlè Lietuvos laisvinimo veiklos derinimą JAV. Atkurtosios Lietuvos santvarka buvo įvardyta kaip demokratinè respublika, besitvarkanti pagal $1922 \mathrm{~m}$. Konstituciją. Tai atitiko parlamentinès respublikos modeli, tačiau dèl skirtingu požiūrių i 1926 metu ìvykius Lietuvoje, šios organizacijos vienybè ilgai netruko.

2.2. $1941 \mathrm{~m}$. birželio $7 \mathrm{~d}$. tautininkai, atsiskyrę nuo ALT, ikūrè Lietuvai vaduoti sajunga, kurios centrine asmenybe tapo i JAV atvykęs Prezidentas A. Smetona. Po tragiškos jo žūties LVS 1944 m. vasario 6 d. persiorganizavo į Amerikos lietuvių misiją. Organizacija užsibrèžè tikslą propaguoti Lietuvos laisvès bylą JAV vyriausybèje ir visuomeneje. Pritardama Vyriausiojo Lietuvos išlaisvinimo komiteto $1944 \mathrm{~m}$. vasario 16 d. atsišaukimui, ALM pasisakẻ už atkurtos nepriklausomos Lietuvos valstybès tęstinumą ir tvarkymąsi pagal $1938 \mathrm{~m}$. Konstitucija, kurioje įtvirtintas prezidentinès respublikos modelis.

2.3. Tarpininkaujant VLIK'ui, $1947 \mathrm{~m}$. pavyko suvesti tautininkus ir ALT i derybas, po kuriu $1948 \mathrm{~m}$. sausio $11 \mathrm{~d}$. ALT vèl suvienijo visas keturias JAV lietuvių politines sroves: katalikus, socialistus, sandariečius ir tautininkus. Tais pačiais metais atsinaujinusios organizacijos statute itvirtintas siekis - atkurtoji nepriklausoma Lietuva bus demokratinė respublika, tačiau nenurodoma, pagal kurių metų konstituciją tvarkytųsi išsilaisvinęs kraštas. 


\title{
THE LITHUANIAN AMERICAN COUNCIL'S VISION OF THE LIBERATED LITHUANIA IN THE 5OS OF THE 20TH C.: BETWEEN PARLIAMENTARY AND PRESIDENTIAL REPUBLICS
}

\author{
JUOZAS BANIONIS
}

\section{Summary}

Keywords: emigration, democratic Lithuania, Constitution of 1922, Constitution of 1938 .

The article discusses the sprouts of Lithuania's liberation in the USA, where Lithuanian emigrants of the previous waves were already active in the $50 \mathrm{~s}$ of the 20th century, and discussions about the future political system of the liberated Lithuania were underway. The emigrants had set up the Council for the Liberation of Lithuania (Lietuvai gelbèti taryba - LGT) back in August of 1940, which was renamed into the Lithuanian American Council (Amerikos lietuviu taryba-ALT) in May, 1941. Initially, this organization consolidated four main political streams of the Lithuanian emigration: Roman Catholics, socialists, members of the Santara movement and nationalists. The nationalists, having adopted a favourable attitude to the President Antanas Smetona, separated and established the Union for the Liberation of Lithuania (Lietuvai vaduotisajunga - LVS) in June, 1941. After the President's tragic death (January 9, 1944), this organization developed into the Mission of American Lithuanians (Amerikos lietuviu misija $A L M)$. The simultaneous existence of two organizations concerned with activities of Lithuania's liberation obstructed the formation of undivided policies. The proclamation "To the Lithuanian nation" by the Senior Committee for the Liberation of Lithuanians of February 16, 1944 states that "after the liberation of Lithuania from the occupational regime, the Constitution of Lithuania of 1938 shall not lose its power until it is legally and accordingly revised" and emphasizes the necessity for a presidential republic. The Senior Committee for the Liberation of Lithuania (Vyriausiasis Lietuvos išlaisvinimo komitetas - VLIK), who had gained much authority in the West, managed to bring the above-mentioned organizations to negotiations. In January of 1948, ALT once again was combining the four patriotic Lithuanian political streams. 